\title{
Impact of Perceived Academic Stress and Depression on Self Efficacy Beliefs among University Students during Online Learning in Peninsula, Malaysia
}

\author{
Mutiu Olagoke Salami ${ }^{1 *}$, Rahmattullah Khan ${ }^{2}$, Muhammed Yusuf ${ }^{3}$, Asma Perveen ${ }^{4}$, and \\ Mohammed Y.M. Mai ${ }^{5}$ \\ 1,2,3,4,5 Universiti Pendidikan Sultan Idris, Malaysia \\ *e-mail: salami@fpm.upsi.edu.my
}

\begin{abstract}
Due to the COVID-19 pandemic, a new challenge has developed specifically among students faced with online learning. The challenge that arises from this type of learning is that the students faced some uncertainties and negative emotional states. This study examined the impact of perceived academic stress and depression on self-efficacy beliefs among university students studying online. One hundred twenty-three participants from two public Universities in Peninsula Malaysia participated through an online google form, which consists of three instruments which are Perception of Academic Stress Scale (PASS), General Self-efficacy (GSE), as well as Depression, Anxiety and Stress Scale (DASS). Findings from Pearson correlation revealed a low negative correlation between general selfefficacy and stress $(r=-.269, p<0.01)$. On the other hand, the result of a simple linear regression between self-efficacy and perceived academic stress was significant with $B=-2.30, p<0.05$. Students with higher levels of academic stress tend to experience depressive symptoms, while selfefficacy was a predictor of perceived academic stress. Considering the current unpredictable pandemic situation, with support from school psychologists and counselors, students are expected to heighten their cognitive drives and beliefs, including the motivation to overcome the challenges inherent in online learning.
\end{abstract}

Keywords:

Depression; Online Learning; Self-Efficacy; Academic Stress; University Students

\begin{abstract}
ABSTRAK
Karena pandemi COVID-19, tantangan baru telah berkembang khususnya di kalangan siswa yang dihadapkan dengan pembelajaran online.
\end{abstract}


Tantangan yang muncul dari jenis pembelajaran ini adalah siswa menghadapi beberapa ketidakpastian dan keadaan emosi negatif. Penelitian ini dilakukan untuk menguji dampak stres akademik yang dirasakan dan depresi pada keyakinan efikasi diri di kalangan mahasiswa yang belajar online. Sebanyak 123 peserta dari dua universitas negeri di Peninsula Malaysia berpartisipasi melalui online google form yang terdiri dari tiga instrumen yaitu Perception of Academic Stress Scale (PASS), General Selfefficacy (GSE), serta Depression, Anxiety and Stress Scale (DASS). . Temuan dari korelasi Pearson mengungkapkan ada korelasi negatif yang rendah antara efikasi diri umum dan stres $(r=-.269, p<0,01)$. Di sisi lain, hasil regresi linier sederhana antara efikasi diri dan stres akademik yang dirasakan signifikan dengan $B=-2,30, p<0,05$. Siswa dengan tingkat stres akademik yang lebih tinggi cenderung mengalami gejala depresi sementara efikasi diri adalah prediktor untuk stres akademik yang dirasakan. Mempertimbangkan situasi pandemi yang tidak dapat diprediksi baru-baru ini, dengan dukungan dari psikolog dan konselor sekolah, siswa diharapkan untuk meningkatkan dorongan dan keyakinan kognitif mereka, termasuk motivasi untuk mengatasi tantangan yang melekat dalam pembelajaran online.

\section{Kata kunci:}

Depresi, Pembelajaran Online, Kemanjuran Diri, Stres Akademik, Mahasiswa

\section{Introduction}

Online study and learning being the new norm in the current pandemic, has triggered tremendous challenges to both students and their parents (Burgess \& Sievertsen, 2020). This global reality is already taking its toll on students. Generally, the COVID-19 pandemic is inherently accompanied by strict lockdown and isolation measures, which involve a sedentary and disturbing social life and virtual learning (Chandra, 2021). This challenging situation has made it stressful for students and educators alike with no access to group classroom activities and interactive learning. So, despite not being within the school environment, recent reports point towards the heightened perception of academic stress among university students (American Psychological Association, 2020).

Furthermore, these challenges have triggered uncertainties and negative emotional states of depression, anxiety, and stress (Mishra, Gupta, \& Shree, 2020). The prevalence of depression and anxiety symptomology among university students has been regularly reported from various studies (Aktekin et al., 2001; Bruffaerts et al., 2018). Thus, the uncertain effect posed by the ongoing pandemic might have steeply risen the situation. Before the pandemic, findings from systematic review revealed enormous differences observed in epidemiological benchmarking, resulting from using varying measures of depression and anxiety among university students (Ibrahim et al., 2013). 
Perceived academic stress is often seen as a unique set of academic stressors connected to student experience (Bedewy \& Gabriel, 2015). While students are currently experiencing homerelated stress related to academic life, there are other forms of stressors affecting students, including perceived pressure to perform. According to Bedewy and Gabriel (2015), specific immediate external stressors from expectations of parents' and teachers' peer's competition, including critical remarks on students' academic performance, often placed some pressure on the students. However, one possible means of adjusting to this kind of situation lies with the cognitive strength of believing in one's capabilities to organize and accomplish the courses of action required to produce set goals (Bandura, 1977).

Generally, self-evaluating one's competence to effectively execute a course of action that is essential to reach desired outcomes is referred to as self-efficacy (Bandura, 1977, 1982). This also accounts for a person's belief that his abilities to do things impact his performance and how he reacts to challenging situations (Eldredge et al., 2016). Thus, it is more meaningful to measure academic self-efficacy in academic settings since it can be termed to be a students' confidence in his ability to carry out academic tasks as preparing for classes, mid-term exams, and various assignments. Hence, the present study examines the correlations between self-efficacy and perceived academic stress among university students studying online.

Bandura (1995) speculated that self-efficacy beliefs affect college outcomes due to increased students' motivation and mastery to attend to challenging academic tasks. He also proposed that self-efficacy beliefs help to foster the proficient use of acquired knowledge and skills. In addition, he suggested that perceived self-efficacy influences which kind of coping behavior a person initiates when faced with challenging situations and determines how much effort the person will be expended to reach set goals (Bandura, 1999). In a study, Torres and Solberg (2001) found a positive correlation between academic self-efficacy and the number of hours students spent studying.

It is believed that people with firm self-efficacy beliefs tend to see a task as a challenge, thereby making them persist at managing the task. Thus, self-efficacy beliefs as a motivational construct affect the perception of external demands and mediate the relationship between external stressors and psychological stress (Bandura, 1995). In a study that examined the link between emotional self-efficacy and educational stress, findings revealed that there was a negative correlation between emotional self-efficacy and educational stress, indicating that educational stress was negatively predicted by emotional self-efficacy (Arslan, 2017).

In recent times, researchers have considered self-efficacy an influential motivational, affective, and cognitive determinant of student behavior, including being a significant influence on their efforts, persistence, self-regulation, and achievements (Honicke \& Broadbent, 2016; Zumbrunn et al., 2019). Furthermore, the recent challenges posed by the ongoing pandemic situation have called for greater attention in helping students to foster their self-efficacy beliefs due to its significance in controlling stress (Sahin \& Çetin, 2017; Lanin et al., 2019). Hence, being able 
to translate cognitive strength to adaptive functioning remain paramount for students during challenging times.

The current pandemic period has pushed university students to face a wide variety of demands, involving both academic and non-academic, which invariably could affect their wellbeing. There are reports linking students with increased stress levels and anxiety, including symptoms of depression due to changes to learning, the uncertainty of university education, decreased family income, technological issues related to online classes, among others (Aristovnik et al., 2020). With stress being triggered by the ongoing pandemic, stressors experienced by students majorly include financial restraints, uncertainty related to their academic performance, and future career pursuits (Sundarasen et al., 2020).

While these adverse outcomes of stress can be connected to academic-related stress like adverse academic outcomes, reduced cognitive abilities, coping problems, and incompleteness of university studies, there are more concerns about the health consequences. Findings revealed that academic stress is related to specific somatic and psychological symptoms, including having problems with appetite, sleep disturbances, headaches, and increased heart rate (Nelwati, Mckenna, \& Plummer, 2012). Furthermore, the university context is possibly stressful, and the situation generated by the COVID-19 pandemic expectedly hurts students. In a study among 427 Spanish students, findings revealed that those with higher anxiety levels tend to express more negative emotions and perceive themselves with reduced academic self-efficacy (Alemany-Arrebola et al., 2020).

The correlation between academic stress and depression-related symptoms calls for more significant concern during the ongoing pandemic as students are subjected to online study with little or no interaction with others whatsoever. Hence, the present study examines the relationship between general self-efficacy, stress, and depression among university students during online learning.

\section{Methods}

The present study used a sample of 123 undergraduate students from two Public Universities in Peninsula Malaysia. While the data was collected via a google form online, the inclusion criteria were for participants to be undergraduate students at the time of the study. Most of the participants are female and study the course of psychology. More than half of the participants engaged in online study for four months but less than a year even though the online study trend has been conducted for a year. Refer to Table 1 for detailed demographic information.

\subsection{Perceived Academic Stress}

The Perception of Academic Stress Scale (PASS) (Bedewy \& Gabriel, 2015) is a self-report instrument that incorporates four constructs; perceived pressure to perform, academic selfperception, perceived time restraint, and perceived workload. The 18-item scale is used to assess 
stresses related to academic expectations (like "The unrealistic expectations of my parents stress me out"), stresses related to faculty work, and examinations (like "I believe that the amount of work assignment is too much"), and stresses related to students' academic self-perceptions (like "I think that my worry about examinations is the weakness of character"). The participants responded on a 5-point Likert scale from strongly disagree (1) to strongly agree (5).

Table 1. Demographic characteristics of samples $(n=123)$

\begin{tabular}{lll}
\hline Characteristics & No. & \% \\
\hline Gender & 14 & 11.4 \\
Male & 109 & 88.6 \\
Female & & \\
Course of Study & 16 & 13.0 \\
Agricultural Science & 1 & 0.8 \\
Biomolecular Science & 1 & 0.8 \\
Business Management & 1 & 0.8 \\
Manufacturing & 104 & 84.6 \\
Psychology & & \\
Period of Online Study & 2 & 1.6 \\
Three months or less & 66 & 53.7 \\
Four months or more & 55 & 44.7 \\
More than a year &
\end{tabular}

\subsection{Self-Efficacy}

The General Self-Efficacy Scale from Schwarzer and Jerusalem (1996) was used to measure self-efficacy beliefs. The scale has ten items with items like ("I can solve difficult problems if I try hard enough"). The participants responded to the items based on a Likert scale from 1 (never) to 5 (always). The psychometric properties of the GSE were good, in which internal reliability for GSE = Cronbach's alphas between .76 and .90. For validity, the GSE Scale is correlated to emotion, optimism, work satisfaction, while negative coefficients were found for depression, stress, health complaints, burnout, and anxiety (Schwarzer \& Jerusalem, 1996).

\subsection{Depression and Anxiety}

The Depression, Anxiety, and Stress Scale (DASS) is a 21-item self-report. The DASS-21 is a set of three self-report scales designed to measure the emotional states of depression, anxiety, and stress (Lovibond \& Lovibond, 1995). The participants responded to the items based on a Likert scale from 0 (Did not apply to me at all) to 3 (Applied to me very much or most of the time). The present study adopts the dass-21 due to its well-established psychometric properties, as it has been widely used and confirmed with reliable and valid normative data among Australian University Students (Crawford et al., 2011). Besides, the DASS-21 has been confirmed with Cronbach's alpha values of 0.92, 0.86, and 0.86, respectively, for Depression, Anxiety, and Stress domains in Malaysia (Musa \& Aidid, 2020). 


\subsection{Procedures}

The informed consent of all participants was obtained, and the data collection was carried out at the end of the semester to avoid periods of high academic demands (e.g., work overload and preparation for exams) that could influence their responses to the set of questionnaires. On the first page of the data set, the participants were informed of the aims of the study and were asked to participate; they were also guaranteed anonymity and the confidentiality of their responses as they were not required to state their names, matric number, or other personal details that can be connected to their identity. In addition, the researcher also explained that their participation is voluntary. The questionnaires were administered online without any time limit. Data collected were collated and analyzed using descriptive statistics (means and standard deviation) and Analysis of variance (ANOVA). Analysis of the data also includes correlational statistics and Simple linear regression.

\section{Results and Discussion}

The present study examines the relationship between general self-efficacy, stress, and depression among university students during online learning. The ANOVA test was conducted to examine the difference in perceived academic stress among students engaging in online learning. Three groups of students engaged in online learning with students who studied online for three months or less, students who studied online for four months or more, and students who studied online for more than a year. The result of the ANOVA test showed an insignificant difference between those three groups of students with $p>.05$ (Table 2). Thus, all the students in this study showed the same level of perceived academic stress regardless of their time on online learning.

Table 2. The difference of perceived academic stress among students engaging in online learning

\begin{tabular}{llllll}
\hline & $\begin{array}{l}\text { Sum of } \\
\text { Squares }\end{array}$ & Df & Mean Square & F & Sig. \\
\hline Between Groups & 182.347 & 2 & 91.173 & .632 & .533 \\
Within Groups & 17306.694 & 120 & 144.222 & & \\
Total & 17489.041 & 122 & & & \\
\hline
\end{tabular}

Results from the ANOVA test reveal there is no difference in the relationship between self-efficacy, depression, and anxiety based on the length of online study.

Besides, a Pearson correlation was used to examine the relationship between general selfefficacy, stress, and depression. The result showed a low negative correlation between general selfefficacy and stress $(r=-.269, p<0.01)$, which invariably means that the higher the students' selfefficacy, the lower their perceived academic stress. On the other hand, findings revealed a significantly high positive correlation between students' perception of academic stress and depression $(r=.726, p<0.01)$, which means that a high degree of stress tends to have a high degree of depression. 
Since there is a significant relationship between general self-efficacy and stress, a further analysis was conducted on both variables to see whether general self-efficacy was a predictor of students' perceived academic stress. The result of simple linear regression was significant with $B=-$ 2.30, $p<0.05$ (Table 4). This showed that when the students' self-efficacy decreased by .230 units, the amount of stress increased by one unit, indicating that general self-efficacy is a predictor of perceived academic stress.

Table 3. Correlation between the general self-efficacy beliefs perceived academic stress and depression

\begin{tabular}{lccc}
\hline & $\mathbf{1}$ & $\mathbf{2}$ & $\mathbf{3}$ \\
\hline 1. General Self-Efficacy & - & & \\
2. Stress & $-.269^{* *}$ & - & - \\
3. Depression & -.169 & $.726^{* *}$ & - \\
$* * p<0.01$ & & &
\end{tabular}

Table 4. Simple linear regression general self-efficacy and perceived academic stress

\begin{tabular}{lccccc}
\hline & \multicolumn{2}{c}{$\begin{array}{c}\text { Unstandardized } \\
\text { Coefficients }\end{array}$} & $\begin{array}{c}\text { Standardized } \\
\text { Coefficients }\end{array}$ & t & Sig. \\
\cline { 2 - 4 } & B & Std. Error & Beta & & \\
\hline Constant & 16.164 & 2.226 & & 7.262 & .000 \\
General Self-Efficacy & -.230 & .075 & -.269 & -3.067 & .003 \\
\hline
\end{tabular}

We examine the difference in perceived academic stress among students engaging in online learning. In the three groups of students engaging in online learning, findings revealed no significant differences between the groups. This means that there is no difference in the perception of academic stress between students with online study experience for less than three months, for more than four months, and more than a year. Moreover, results showed a low negative correlation between general self-efficacy and perceived academic stress, where lower perceived academic stress scores were correlated with increasing self-efficacy scores. It further implies that the higher the students' self-efficacy beliefs, the lower their perceived academic stress. This finding can be connected to Arslan (2017), in which educational stress was negatively correlated with emotional self-efficacy. It is an indication that students who believe in accomplishing set goals tend to address the challenging situation, including positively interpreting academic demands as challenges that can be addressed.

In addition, findings also showed a positive correlation between perceived academic stress and depression, indicating that students with higher levels of academic stress tend to experience depressive symptoms. This finding can be linked to Alemany-Arrebola et al. (2020), in which students who show a higher level of anxiety tend to express more negative emotions and perceive themselves with less academic self-efficacy. The overwhelming covid pandemic that has triggered recent stressful situations like the lockdowns, together with some critical events like financial 
strains and lower family income, can be easily linked to perceived academic stress and depression among students. In addition, findings from simple linear regression showed that general selfefficacy is a predictor of perceived academic stress. This is supported by the results of Torres and Solberg (2001) and Arslan (2017). Though, with less attention in the Malaysian context, this inverse relationship between self-efficacy beliefs and academic stress is particularly significant among college students as it may affect their academic performance. The outcomes of several studies highlighted above reflect the vital role of self-efficacy beliefs in buffering against perceived academic stress, effective coping mechanism, and other positive desired outcomes.

\section{Conclusions}

In examining the impact of perceived academic stress and depression on self-efficacy beliefs among university students studying online, findings revealed the connection between perceived academic stress and depression, indicating that students with higher levels of academic stress tend to experience depressive symptoms. While there is no difference in the relationship between selfefficacy, depression, and anxiety based on the length of online study, findings showed the correlation between general self-efficacy and perceived academic stress, which suggests that the higher the students' self-efficacy beliefs, the lower their perceived academic stress. In all, it could be deduced that the COVID-19 pandemic is a significant stressor with a negative impact on students that often triggers negative emotions like anxiety and depression on the one hand and triggers reduced self-efficacy beliefs on the other.

In terms of the potential limitation of our study, in addition to the modest sample size, is the question of representativeness of our sample because all participants were university students who participated through an online platform. However, the findings of the present study shed more light on the positive construct of self-efficacy belief. Considering the current and unpredictable pandemic situation, students are expected to heighten their cognitive drives and beliefs, including the motivation to drive through the challenges inherent in online learning. Coupled with other emotional distress and depression, school psychologists, teachers, and other helping school professionals need to see the need to boost students' self-efficacy beliefs and mastery orientation.

\section{References}

Aktekin, M., Karaman, T., Senol, Y.Y., Erdem, S., Erengin, H., \& Akaydin, M. (2001). Anxiety, depression and stressful life events among medical students: A prospective study in Antalya, Turkey. Medical Education. 35, 12-17.

Alemany-Arrebola I., Rojas-Ruiz G., Granda-Vera J., \& Mingorance-Estrada Á., C. (2020). Influence of COVID-19 on the Perception of Academic Self-Efficacy, State Anxiety, and Trait Anxiety in College Students. Frontiers in Psychology. 11:570017. DOI: 10.3389/fpsyg.2020.570017

American Psychological Association .(2020). Student mental health during and after COVID-19: How can schools identify youth who need support? Retrieved from https://www.apa.org/topics/covid-19/student-mental-health. 
Aristovnik, A., Kerzič, D., Ravselj, D., Tomazevič, N., \& Umek, L. (2020). Impacts of the COVID19 pandemic on life of higher education students: A global perspective. Retrieved from DOI: https://doi.org/10.20944/preprints202008.0246.v2

Arslan, N. (2017). Investigating the relationship between educational stress and emotional selfefficacy. Universal Journal of Educational Research, 5(10), 1736-1740. DOI: 10.13189/ujer.2017.051010

Bandura, A. (1977). Self-efficacy: Toward a unifying theory of behavioral change. Psychological Review, 84(2), 191-215. DOI: https://doi.org/10.1037/0033-295X.84.2.191

Bandura, A. (1982). Self-efficacy mechanism in human agency. American Psychologist, 37,(2), 122-147. DOI: https://doi.org/10.1037/0003-066X.37.2.122

Bandura, A. (1995). Exercise of personal and collective efficacy in changing societies. In A. Bandura (Ed), Self-efficacy in changing societies. Cambridge, MA: Cambridge University Press.

Bandura, A. (1999). Social cognitive theory of personality. In L. A. Pervin \& O. P. John (Eds.), Handbook of personality: Theory and research (pp. 154-196). New York, NY: Guilford Press.

Bedewy, D., \& Gabriel, A. (2015). Examining perceptions of academic stress and its sources among university students: The perception of academic stress scale. Health Psychology Open, 30(2), 1-9. DOI: $10.1177 / 2055102915596714$

Bruffaerts, R., Mortier, P., Kiekens, G., Auerbach, R. P., Cuijpers, P., Demyttenaere, K., \& Kessler, R. C. (2018). Mental health problems in college freshmen: Prevalence and academic functioning. Journal of Affective Disorders. 225,97-103.

Burgess, S., Sievertsen, H., H. (2020). Schools, skills, and learning: The impact of COVID-19 on education. Retrieved from https://voxeu.org/article/impact-covid-19-education.

Chandra, Y. (2021), "Online education during COVID-19: perception of academic stress and emotional intelligence coping strategies among college students", Asian Education and Development Studies, 10, 2, 229-238. DOI: https://doi.org/10.1108/AEDS-05-2020-0097

Crawford, J., Cayley, C., Lovibond, P., Wilson, P., \& Hartley, C. (2011). Percentile norms and accompanying interval estimates from an Australian general adult population sample for selfreport mood scales (BAI, BDI, CRSD, CES-D, DASS, DASS-21, STAI-X, STAI-Y, SRDS, and SRAS). Australian Psychologist, 46, 3-14. DOI: 10.1111/j.1742-9544.2010.00003.x

Eldredge, L. K., Markham, C. M., Kok, G., Ruiter, R. A., \& Parcel, G. S. (2016). Planning health promotion programs: An intervention mapping approach. New Jersey: John Wiley \& Sons.

Honicke, T., \& Broadbent, J. (2016). The relation of academic self-efficacy to university student academic performance: a systematic review. Education Research Review, 17, 63-84. DOI: 10.1016/j.edurev.2015.11.002

Ibrahim, A., Kelly, S., Adams, C., \& Glazebrook. (2013). A systematic review of studies of depression prevalence in university students. Journal of Psychiatric Research, 47(3), 391400. DOI: $10.1016 /$ j.jpsychires.2012.11.015

Lanin, D. G., Guyll, M., Cornish, M. A., Vogel, D. L., and Madon, S. (2019). The importance of counseling self-efficacy: physiologic stress in student helpers. Journal of College Student Psychotherapy, 33(2), 1-11. DOI: 10.1080/87568225.2018.1424598

Lovibond, S. H., \& Lovibond, P. (1995). Manual for the Depression Anxiety Stress Scales (2nd rd.) Sydney, NSW: Psychology Foundation Monograph. 
Mishra, L., Gupta, T., \& Shree, A. (2020). Online teaching-learning in higher education during lockdown period of COVID-19 pandemic. International Journal of Educational Research Open 1. 100012 DOI: 10.1016/j.ijedro.2020.100012

Nelwati, D., Mckenna, L., Plummer, V. (2012). Indonesian student nurses' perceptions of stress in clinical learning: A phenomenological study. Journal of Nursing Educational Practise, 3(5), 56-65. DOI: $10.5430 /$ jeep.v3n5p56

Musa, R., \& Aidid, E. M. (2020). Psychometric properties of the depression anxiety stress scale 21item (DASS-21) Malay version among a big sample population of non-Malays in Malaysia. Malaysian Journal of Psychiatry, 29, 1

Sahin, F., \& Çetin, F. (2017). The mediating role of general self-efficacy in the relationship between the big five personality traits and perceived stress: A weekly assessment study. Psychological Studies, 62(1), 35-46. DOI: 10.1007/s12646-016-0382-6

Schwarzer, R., \& Jerusalem, M. (1995). Generalized Self-Efficacy scale. In J. Weinman, S. Wright, \& M. Johnston (Eds.), Measures in health psychology: A user's portfolio. Causal and control beliefs (pp. 35-37). Windsor, UK: NFER-NELSON.

Sundarasen, S., Chinna, K., Kamaludin, K., Nurunnabi, M., Mohammad Baloch, G., Khoshaim, H. B., Abid Hossain, S. F., \& Sukayt, A. (2020). Psychological Impact of COVID-19 and Lockdown among University Students in Malaysia: Implications and Policy Recommendations. International Journal of Environment Research and Public Health. 17, 6206; DOI: 10.3390/ijerph17176206.

Torres, J., B. \& Solberg, V. S. H. (2001). Role of Self-Efficacy, Stress, Social Integration, and Family Support in Latino College Student Persistence and Health. Journal of Vocational Behaviour 59(1):53-63. DOI:10.1006/jvbe.2000.1785.

Zumbrunn, S., Broda, M., Varier, S., and Conklin, S. (2019). Examining the multidimensional role of self-efficacy for writing on student writing self-regulation and grades in elementary and high school. British Journal of Educational Psychology, 90(2). DOI: 10.1111/bjep.12315. 